\title{
Portuguese Citizens' Support for Democracy: 40 Years after the Carnation Revolution
}

\section{Edalina Rodrigues Sanches \& Ekaterina Gorbunova}

To cite this article: Edalina Rodrigues Sanches \& Ekaterina Gorbunova (2016): Portuguese Citizens' Support for Democracy: 40 Years after the Carnation Revolution, South European Society and Politics, DOI: 10.1080/13608746.2015.1130680

To link to this article: http://dx.doi.org/10.1080/13608746.2015.1130680

册 Published online: 23 Mar 2016.

Submit your article to this journal $\pi$

Џ Article views: 27

Q View related articles $₫$

View Crossmark data $\asymp$ 


\title{
Portuguese Citizens' Support for Democracy: 40 Years after the Carnation Revolution
}

\author{
Edalina Rodrigues Sanches and Ekaterina Gorbunova
}

\begin{abstract}
Forty years after the Carnation Revolution, the relatively young Portuguese democracy is experiencing dramatically low levels of public specific support for democracy. This article tests the leverage of demand-side and supply-side accounts to explain differentials in public satisfaction with democracy. Through ordinary least squares regression analyses that draw on the unique data of the 'Barometer 40 Years of Democracy in Portugal (2014)', this articles shows that age cohort, identification with extreme parties, evaluation of the country's political past, and economic performance are strong correlates of citizens' specific support for democracy.
\end{abstract}

\section{KEYWORDS}

Satisfaction with democracy;

Carnation Revolution;

political past; economic

performance; Portugal

The Carnation Revolution that took place in Portugal 40 years ago, on 25 April 1974, did not just mean the end of the Estado Novo (New State) authoritarian regime; it initiated the 'third wave' of democratisation, which, in turn, triggered an exponential growth in democracies throughout the world. Though democracy remains widely accepted as the only game in town, studies that examine citizens' attitudes towards democracy in many Western polities have recurrently pointed to significantly high levels of public dissatisfaction with the way democracy works, as well as with key political actors and institutions, fitting a common tendency of disengagement from democracy (Dalton 2004; Torcal \& Montero 2006).

Existing scholarship offers numerous explanations of this phenomenon. At the individual/ micro level, demand-side post-modernisation theories emphasise'long-term processes of human development, especially growing levels of literacy, education, and cognitive skills' (Norris 2011, p. 6) that have led to generational shifts towards more liberal -'self-expression' or'emancipative' - values (Inglehart \& Welzel 2003; 2005). On the supply side, possible explanatory variables include those relating to the system's performance, namely, key political actors' performance and quality of public goods and of policy outcomes (Mishler \& Rose 1994; Magalhães 2014).

At the macro-level, two main sets of environmental factors have often been considered. The first refers to a country's institutional design, namely, the type of regime, the constitutional framework, the electoral formula and the party system format (Anderson \& Guillory 1997; Aarts \& Thomassen 2008). All these institutional characteristics have been thought to generate systemic incentives or constraints for public satisfaction with democracy. The other set of factors stems from a country's macro-economic performance, indicators such as gross domestic product (GDP) growth, unemployment and inflation (Clarke, Dutt \& Kornberg 1993; 
Polavieja 2012) featuring prominently as contextual explanations of why citizens' satisfaction with democracy varies from a cross-sectional perspective.

In Portugal, levels of specific support for democracy at the citizen level have been steadily decreasing, particularly since the beginning of the twenty-first century, and nowadays the country faces the lowest levels of specific support for democracy ever registered in public opinion polls (Magalhães, Lobo \& Gorbunova 2014; Gorbunova, Sanches \& Lobo 2015). Studies that have examined this phenomenon are scarce (e.g. Teixeira, Tsatsanis \& Belchior 2014; Magalhães 2005) but fruitful in the way they have addressed the sources of different attitudes towards the democratic political system/regime (like specific and diffuse support; illegitimacy, disaffection and discontent). However, there remain many unexplored questions with regard to specific support for democracy, which is the phenomenon of interest here. This article considers new factors that have not been accounted for in previous studies and that might prove key for the Portuguese case.

Firstly, it proposes, a different take on demand-side explanations, taking into account the specificity of the country's political culture. Instead of considering linear effects of age, it looks at cohort effects. Such approach might prove more meaningful given the fact that, being a quite young - though consolidated - democracy, Portugal still has a significant share of population who experienced early socialisation under a non-democratic regime and have memories of the transition to democracy. Moreover, to better trace the effects of this political socialisation we consider a set of other factors that express citizens' attitudes towards the democratic transition and the Estado Novo regime. Such an analysis is unique within the literature on Portugal, even though many authors have theorised about these issues. Indeed, it has been argued that the Portuguese transition - by social revolution created better conditions for the emergence of democratic practices closer to the goal of full political equality among citizens than did the Spanish regime-led transition by reform (Fishman 2011). From another perspective, it has been sustained that the nature of Portugal's transition created a double legacy, affecting both attitudes towards the authoritarian regime and future democratic aspirations (Pinto 2006, p. 176).

Secondly, in terms of political attitudes, this article proposes reframing the analysis of the effects of party identification, by examining levels of support for democracy in cases of no party identification and of identification with either mainstream or extreme parties. This is worthwhile, as, on the one hand, the lack of party identification is often seen as a symptom of citizens' political disengagement and consequent democratic discontent, which could not be true for our case; on the other hand, ideological polarisation has been often linked to more critical assessments of representative democracy.

Lastly, on the supply side, instead of looking at traditional short-term factors, we consider citizens' perceptions of whether a set of key policy areas have improved or worsened when compared with the previous authoritarian regime. It seems logical to suppose that the severe economic crisis and the consequent implementation of the troika-led austerity programme in 2011 have negatively affected citizens' evaluations of the quality of government performance and, therefore, their satisfaction with the way democracy is working in the country.

To explore these demand-side and supply-side explanations we draw on the data from the 'Barometer 40 Years of Democracy in Portugal (2014)', which was carried out by the Barometer of the Quality of Democracy project ${ }^{1}$. This survey aimed to assess Portuguese citizens' perceptions of the pre-1974 regime, the process of democratic transition and the 
current state of democracy in the country. Therefore it allows a comprehensive analysis of the issues raised above.

The article is structured as follows. We begin by briefly summarising the key theories of satisfaction with democracy as relevant to our case. Then we present the framework for the analysis of satisfaction with democracy in Portugal, describe how both the dependent and independent variables were operationalised and present some descriptive results. In the main empirical section, we estimate the effects of demand-side and supply-side predictors for citizens' satisfaction with democracy, through four ordinary least squares (OLS) regression models. We finish with a discussion of the results.

\section{Satisfaction with democracy and its determinants}

According to various scholars (Easton 1975; Norris 2011), the level of public satisfaction with democratic performance is one of the most important indicators of citizens' support of the regime, as well as a factor of democratic consolidation and stability. Indeed, people can express negative attitudes towards specific elements of the political system - political parties, government leaders or members of parliament - but in democratic states these actors can always be penalised in regular elections. 'If the public loses faith in the quality of their democracy ... this can have potentially far more significant consequences for regime stability' (Norris 2011, p. 4).

Recent opinion polls on citizens' support for democracy reveal that only 50 per cent of Europeans are very/fairly satisfied with the way democracy works in their country, ${ }^{2}$ revealing an increasing 'confidence gap' and a growing popular discontent in Western societies (Pharr \& Putnam 2000; Dalton 2004; Norris 2011). But what are the causes of this phenomenon? Among a proliferation of theories and studies, two major groups of explanatory accounts can be chosen as relevant to our study.

\section{Demand-side explanations}

Demand-side explanations of satisfaction with democracy focus on societal factors, to be specific, on citizens' socio-political and socio-cultural characteristics. In one of the most coherently elaborated attempts to describe the configurations of cultural values and their relation to democratic development, Inglehart and Welzel proposed a distinction between two dimensions: the first contrasted traditional and secular-rational values, while the second opposed survival and self-expression values (Inglehart \&Welzel 2003; 2005). The core values constituting the type of political culture consistent with democratic development are the so called 'self-expression' or 'emancipative' values, which 'are present in a political culture so far as the public emphasizes liberty and participation, public self-expression, tolerance of diversity, interpersonal trust and life satisfaction' (Inglehart \&Welzel 2003, p. 64). In addition, this dimension reflects a polarisation of views on the tolerance of external groups, gender issues and civil liberties, thus contributing to changes in public aspirations concerning democracy and satisfaction with perceived democratic performance.

In her already classical work, Norris (2011) builds on modernisation theories to explore the causes of democratic deficit (i.e. a rising gap between democratic aspirations and the evaluations of democratic performance). She generally confirms the theoretical premises by concluding that'educational levels, self-expression values, social trust, and associational 
activism all help to predict higher democratic aspiration ... most importantly ... only the effects of education widened the democratic deficit; self-expression values, social trust and associational activism were significantly linked with greater democratic satisfaction, not less' (2011, p. 2).

Studies focusing on the Portuguese case have shown that these accounts matter, though the results seem quite puzzling. In particular, it has been demonstrated that post-materialist values are strong correlates of diffuse support but not of specific support; additionally education was only proved significant in explaining specific support and age seemed to have lost significant effect on both specific and diffuse support from a longitudinal perspective (Teixeira, Tsatsanis \& Belchior 2014).

The second set of demand-side explanations explores the effects of political attitudes and party identification on satisfaction with the way democracy works. Anderson and Guillory (1997, p. 68) prove that 'people who voted for a governing party - either the governing party or one among several in a governing coalition - are almost by definition more likely to believe that the government is interested in and responsive to their needs. They are inclined to be satisfied with the government's performance ... and with the way the system works.' On the contrary, 'because the political system is a friendlier place for people who identify with the governing party ... losers are less satisfied with the way democracy works than are winners'. If people feel that the rules of the election process allow the party they voted for to be elected, they are more likely to feel that institutions are responsive to their needs. If that is the case, they will also display higher levels of trust in the political system, and, consequently, of satisfaction with the government's performance and with the way the system works (Lambert et al. 1986; Anderson et al. 2005). Conversely, those whose preferred party loses an election are more likely to feel that their voice is excluded from the decisionmaking process, which may trigger sentiments of dissatisfaction with and distrust in political institutions (Cho 2004).

Curini, Jou and Memoli (2012) add an interesting dimension to this discussion by introducing a distinction not only between present winners and losers, but also'between voters who have previous (especially recent) experience of losing and those who do not' $^{\prime}$ p. 1). Both current and recent winners are expected to express higher levels of satisfaction with democracy than those whose parties have been excluded from power for a long time. As we will see further on, this distinction is particularly pertinent to the Portuguese case, as ideologically polarised parties have been also excluded from the government.

Existing research suggests that ideology plays an important role in shaping peoples' political attitudes, and, in particular, their evaluations of democracy (for an overview, see Anderson et al. 2005). If we assume that voters vote for the party that presents the policy programme that is closest to the their policy preferences, then 'an ideologically moderate cabinet, by minimising the average distance between its position and the position of the whole electorate ... should contribute positively to the overall level of satisfaction with democracy' (Curini, Jou \& Memoli 2012, p. 4). Corroborating this hypothesis, Kim (2009) finds a positive link between satisfaction with democracy and the level of ideological congruence between citizens and political parties in eight consolidated democracies: as the congruence between voter and policy positions rises, satisfaction with democracy also increases. Following this logic, citizens who feel closer to a mainstream party should be more satisfied with the way democracy works than those affiliated with extreme parties. 
In terms of left-right differences, several studies have shown a link between the ideological self-placement of individuals and their evaluations of political institutions and processes, by looking at the underlying values and consequent policy choices that characterise parties and voters holding different ideological positions, instead of merely considering the leftright self-placement indicator (see e.g. Fuchs \& Klingemann 1990; Kittilson \& Scarrow 2003; Anderson \& Singer 2008). Still, in the case of Portugal, left-right self-placement has been proved to be a weak predictor of both diffuse and specific support for democracy (Morlino \& Montero 1995; Teixeira, Tsatsanis \& Belchior 2014), and political disaffection (Magalhães 2005).

Finally, the theories of political socialisation can add value to the discussion of possible explanations of citizens' satisfaction with democracy. We should expect that views and evaluations of the pre-transition regime will somehow influence citizens' assessments of the current state of democracy, as, 'although political attitudes are reflections of individual characteristics, they are shaped by a cultural legacy of past political events' (Torcal \& Lago 2006, p. 312). This is especially true for Portugal, which started its democratic transition only 40 years ago and still has a significant share of population that remembers living in a nondemocratic polity. Indeed, dissatisfaction with democracy can be driven and/or enhanced by nostalgia for the past, especially among those groups of citizens socialised to non-democratic values under the authoritarian regime.

However, in the academic literature, this argument has been mainly studied with regard to the post-communist countries (Ekman \& Linde 2005; Gherghina 2010). And while some researchers have mentioned these indicators as possible explanatory factors of attitudes towards democracy in other political contexts (see e.g. Torcal \& Lago 2006), empirical evidence is yet to confirm whether such interpretations are valid. In one of the rare contributions to this topic, Magalhães (2005) examines the effect of political socialisation experiences on political disaffection in Portugal. By distinguishing between those who were born before 1949 (and whose 'most formative experiences in terms of political socialisation took place before the military coup that overthrew the Estado Novo regime') and those who were born after 1948 (and 'have experienced part or whole of their most crucial period of political socialisation under a democratic regime'), he finds an initial cohort effect on political disaffection which eventually disappears when education is controlled for.

\section{Supply-side explanations}

The second major group of explanations is related to regime evaluations, ranging from its macro- and micro-economic outcomes to the delivery of public goods and services. In analysing support for parliaments and regimes in transition toward democracy in Eastern Europe, Mishler and Rose (1994) used indicators of individual economic status, as well as egocentric and sociotropic evaluations of the current economic situation as explanatory variables, and revealed their significant impact. Later, Polavieja (2012) also found significant effects of both egocentric and sociotropic perceptions of the current economic recession for political trust and satisfaction with democracy in Eurozone countries. Schäfer (2010) demonstrated that in 17 West European countries people with higher socio-economic status were more satisfied with democracy and expressed stronger confidence in parliaments and politicians. However, a more unequal distribution of incomes negatively affected both satisfaction and trust. Likewise, Fuchs and Roller (2006) established a clear empirical 
linkage between economic and government performance and respondents' assessments of democracy in a number of the new democracies in Central and Eastern Europe (see also Torcal \& Magalhães [2009] for analysis of the South European case).

Policy performance explanations, however, have received far less attention from academics. In a study of post-communist states in Central Europe, Evans and Whitefield (1995) conclude that both economic experience and policy performance variables have a significant impact on popular support for democracy, the latter having more weight than the former. Norris (2011), in turn, distinguishes between 'more deeprooted perceptions about how democracy works', corresponding to those judgements of regime performance which are based primarily upon retrospective evaluations of the quality of democratic procedures (so-called 'process accounts'), and 'policy accounts' corresponding to evaluations of the effectiveness of specific public services. Looking at the relationship between diffuse support for democracy and government effectiveness, Magalhães concludes that, 'regardless of long-term processes of social change and socialisation that lend some stability to democratic support, such support is also affected by government performance, if understood in terms of the quality of policy-making and implementation. In democratic regimes, government effectiveness increases support for democracy' (Magalhães 2014, p. 1).

With regard to the Portuguese case, short-term evaluations of the government performance - economic, in the first place - were also found relevant to explaining variance in the satisfaction with democracy (Torcal \& Magalhães 2009). One of the most recent studies that explore the question of democratic legitimacy in Portugal, in the context of the current cross-national economic crisis, also suggests a positive relation between regime performance and support for democracy, though 'individual-level analyses do not reveal any clear patterns' (Teixeira, Tsatsanis \& Belchior 2014, p. 1).

\section{Explaining specific support for democracy in Portugal: methods, variables and data}

Citizens' attitudes regarding the performance of the political system are usually measured through a more or less consensual survey question about 'satisfaction with the functioning of democracy' or 'satisfaction with the way democracy works'. Using David Easton's (1975) classical classification, this indicator should be located midway between the maximum level of diffuse support and the maximum level of specific support, which means that 'citizens' satisfaction with the performance of their democracy can be considered both as an indicator of support for the basic principles of democracy, as well as of citizens specific evaluation of the functioning of the political system in a given concrete situation' (Freire 2003, p. 135; see also Norris 2011). Still, following the mainstream trend, in this article we refer to our dependent variable as an indicator of 'specific support' for democracy, measured by the question 'On the whole, are you very satisfied, fairly satisfied, not very satisfied or not at all satisfied with the way democracy works in in Portugal?'

The independent variables are clustered along the two major strands of the literature previously presented: demand-side and supply-side explanations. In demand-side accounts, age usually stands out as a significant predictor of positive attitudes towards democracy side by side with other factors such as education and support for post-materialist values. In particular, with respect to diffuse support, it has been argued that the younger, more 
educated and more oriented towards post-materialist values display higher levels of support for democratic values and principles (Norris 2011). Nevertheless, empirical research has shown that this is not the case everywhere, particularly as far as specific support is concerned. Portugal is a puzzling case from this perspective, as studies that used dependent variables, corresponding to different types of support for democracy, have only partly corroborated this trend. Teixeira, Tsatsanis and Belchior (2014) examined the determinants of specific and diffuse support before and after the economic crisis and revealed that age had a positive and significant effect on both types of support; however, the effect disappeared after the crisis. On a different note, Magalhães (2005, p. 986) found significant cohort effects on the levels of political disaffection: those who had been 'partially or completely politically socialised under democracy' displayed 'lower levels of political disaffection than the others'. Yet this effect disappeared once education was controlled for. Following this exercise, we propose to test whether satisfaction with democracy significantly varies along three cohorts: born after 1974 (citizens who were politically socialised under democracy), born after 1954 (citizens who were up to 20 years old in 1974) and born before 1954 (citizens with the largest number of years of socialisation under the Estado Novo regime).

Citizens' system of values is measured by an additive index ranging from traditional to liberal values (Cronbach's alpha $=0.8$ ). The index was constructed on the basis of a question in which citizens were asked to evaluate whether a series of social changes Portugal had undergone over the preceding years were more positive than negative or more negative than positive. ${ }^{3}$ The score of 0 (traditional) indicates that none of the changes was seen as positive and the score of 6 (liberal) indicates that all the changes were seen as positive.

In terms of political attitudes, we begin by assessing whether satisfaction with democracy varies for individuals who do not have a party identification and for those identified with either a mainstream party or with an extreme party. To create an operational variable to test this hypothesis, respondents' answers to two questions were combined:'Do you feel close to a political party?' and 'If yes, which one?' According to the survey, 56 per cent of citizens do not feel close to any political party and, among those who said they felt close to a party, 98 per cent mentioned the Socialist Party (Partido Socialista - PS), the Social Democratic Party (Partido Social Democrata - PSD), the Unitary Democratic Coalition (Coligação Democrática Unitária - CDU) - a coalition between the Portuguese Communist Party (Partido Comunista Português - PCP) and the Ecologist Party'The Greens' (Partido Ecologista 'Os Verdes' - PEV) the Democratic and Social Centre-Popular Party (Centro Democrático Social-Partido Popular - CDS-PP) and the Left Bloc (Bloco de Esquerda - BE) (in a descending order of popularity). On the basis of these questions we have elaborated a categorical variable with the following options: no party identification, identification with mainstream parties (PS, PSD and CDS-PP) and identification with extreme parties (CDU and BE).

PS and PSD are the two most significant parties in the Portuguese party system; both are mainstream parties, from, respectively, the left and the right of the political spectrum. By turns, they have been the leading governing parties in the country since the democratic transition. The rightist CDS-PP has been PSD's natural partner of coalition in past and recent elections: the two recently formed a right-wing coalition government (between 2011 and 2015). The CDS-PP can be also perceived as a mainstream party, as, even though it had a more polarised period in the mid-1990s, it never assumed extreme-right stances (Lobo \& Magalhães 2011, p. 85). The CDU and the BE are more ideologically polarised parties (Pereira \& Sanches 2014), representing a traditional and a new left, respectively. These parties have 
never reached the government. Thus, in the Portuguese political landscape, three kinds of factors (left/right and mainstream/extreme positioning, and opposition/incumbent status) mostly overlap: the PS, PSD the CDS-PP are past/present governing parties, being at the same time mainstream parties, whereas the $B E$ and the $C D U$ are opposition parties, representing the extreme left. As our variable covers many aspects of political competition to which, we believe, citizens are sensitive, we have not included a traditional left-right self-placement indicator in our study. Let us recall that studies on the Portuguese case have found weak effects of the latter on attitudes towards democracy (Magalhães 2005; Teixeira, Tsatsanis \& Belchior 2014). Moreover, the mainstream/extreme dichotomy allows us to capture an important dimension of the structure of competition in Portugal, which is considered to be centripetal: major parties compete at the centre of the political spectrum and the electorate tends to vote at the centre (Jalali 2009).

Finally, to account for the views and evaluations of the country's political past, we consider the following questions: 'Do you think that the Portuguese should be proud of the way the transition to democracy was carried out?' which originates a dichotomous variable (yes $=1$, no = 0); and, 'Considering your own experience, or what you heard, do you think the political regime that existed before the 25th of April should be historically known as having had 1) more positive than negative things, 2) as many positive and negative things, or 3 ) more negative than positive things,' which also originates a dichotomous variable opposing option (1) to the other categories.

Supply-side explanations sustain that citizens' level of satisfaction with democracy is contingent upon their evaluations of short-term issues, such as government performance and the state of the economy. We propose to test this claim using an alternative set of questions. In the survey citizens were asked to evaluate whether each one of the group of items representing key policy areas ${ }^{4}$ has improved, stayed the same or worsened vis-à-vis the pre-transition regime. Even though respondents might rest on present information to evaluate each particular item they were also asked to evaluate the performance of the pre1974 regime.

To account for the different weights that policy fields may have for the respondents, as well as for the way they correlate among each other, we have performed a principal components analysis. The results as presented in Table 1 show a solution of three components for the 12 different items considered. The first component - which we designate as Economy - is by far the most important one in terms of explained variance (36.5 per cent). It aggregates evaluations on: economic situation, standard of living, inequality between regions and social inequality. The second component - Social Policies - includes evaluations on health care, education, housing, justice and social security. Lastly, the third component - Risk and Uncertainty - gathers perceptions on corruption, criminality and security and unemployment. Even though one might expect that unemployment would be more associated with economic perceptions, the fact that in individuals' minds it is grouped with perceptions of insecurity can make sense in light of the sociological approaches to risk. Giddens (1990), one of the best-known proponents of this approach, having noted that modern societies have witnessed an increase in sentiments of insecurity, fear and risk, suggested that new forms of democracy should be developed, anchored in social policies that can manage some of those unpredictable risks that societies are facing.

On the basis of this analysis, we have created three indexes, retaining the same names: economy, social policies, and risk and uncertainty. ${ }^{5}$ Finally, we have considered additional 
Table 1. The performance of the democratic regime: economy, social policies, risk and uncertainty.

\begin{tabular}{lccc}
\hline & \multicolumn{3}{c}{ Components } \\
\cline { 2 - 4 } & Economy & Social Policies & Risk and Uncertainty \\
\hline Economic situation & 0.8 & 0.2 & 0.1 \\
Standard of living & 0.8 & 0.3 & 0.0 \\
Inequality between regions & 0.7 & 0.1 & 0.2 \\
Social inequalities & 0.7 & 0.2 & 0.3 \\
Health care & 0.5 & 0.6 & -0.0 \\
Education & 0.1 & 0.8 & 0.1 \\
Housing & 0.1 & 0.8 & 0.0 \\
Justice & 0.4 & 0.4 & 0.2 \\
Social security & 0.2 & 0.7 & 0.1 \\
Corruption & 0.1 & 0.1 & 0.8 \\
Criminality and security & 0.0 & 0.1 & 0.9 \\
Unemployment & 0.3 & 0.1 & 0.7 \\
Explained variance (\%) & 36.5 & 14.2 & 9.5 \\
Cumulative explained variance (\%) & 60.3 & & \\
\hline
\end{tabular}

Source: Barometer 40 Years of Democracy in Portugal (2014).

Notes: Extraction method: principal component analysis. Rotation method: varimax with Kaiser normalization. Rotation converged in six iterations. In bold are the factor loadings which contribute the most for each of the components.

socio-demographic variables as controls - education level, employment status, religiosity and gender - all measured dichotomously.

The results of a bivariate descriptive analysis of satisfaction with democracy and each of the abovementioned independent variables are presented in Table 2 . The results suggest significant differences in average levels of satisfaction with democracy contingent upon individuals' age cohort, political attitudes, pride in how the democratic transition was carried out and evaluation of economic outcomes. Individuals born before 1954 display lower levels of satisfaction with democracy when than individuals in other age cohorts, and the same holds true for those (i) who identify with extreme parties, (ii) who are not proud of the democratic transition process and (iii) who think that economic conditions are worse than during the pre-1974 regime. Together, these variables display the highest-effect size for group mean differences for satisfaction with democracy (as eta values indicate).

Table 2. Dependent and independent variables: descriptive statistics.

\begin{tabular}{|c|c|c|c|c|c|}
\hline & Mean & $N$ & S.E. & Eta & Sig. \\
\hline \multicolumn{6}{|l|}{ Gender } \\
\hline Female $(=0)$ & 2.0 & 638 & 0.8 & 0.0 & n.s. \\
\hline Male $(=1)$ & 2.0 & 597 & 0.8 & & \\
\hline Total & 2.0 & 1,235 & 0.8 & & \\
\hline \multicolumn{6}{|l|}{ Age } \\
\hline Born after 1974 & 2.0 & 433 & 0.8 & 0.1 & $* * *$ \\
\hline Born after 1954 & 2.1 & 525 & 0.8 & 0.0 & n.s. \\
\hline Born before 1954 & 1.8 & 277 & 0.7 & 0.1 & $* * *$ \\
\hline \multicolumn{6}{|l|}{ Education } \\
\hline Less than secondary degree $(=0)$ & 2.0 & 824 & 0.8 & 0.1 & * \\
\hline More than secondary degree $(=1)$ & 2.1 & 411 & 0.8 & & \\
\hline Total & 2.0 & 1,235 & 0.8 & & \\
\hline \multicolumn{6}{|l|}{ Employed } \\
\hline No $(=0)$ & 2.0 & 655 & 0.8 & 0.0 & n.s. \\
\hline Yes $(=1)$ & 2.0 & 580 & 0.8 & & \\
\hline Total & 2.0 & 1,235 & 0.8 & & \\
\hline
\end{tabular}


Table 2. (Continued)

\begin{tabular}{|c|c|c|c|c|c|}
\hline & Mean & $N$ & S.E. & Eta & Sig. \\
\hline \multicolumn{6}{|l|}{ Religiosity } \\
\hline A bit or not at all $(=0)$ & 2.1 & 436 & 0.8 & \multirow[t]{3}{*}{0.1} & \multirow[t]{3}{*}{ ** } \\
\hline Very or fairly $(=1)$ & 2.0 & 796 & 0.8 & & \\
\hline Total & 2.0 & 1,232 & 0.8 & & \\
\hline \multicolumn{6}{|l|}{ No party identification } \\
\hline No $(=0)$ & 2.0 & 464 & 0.8 & \multirow[t]{3}{*}{0.0} & \multirow[t]{3}{*}{ n.s. } \\
\hline Yes $(=1)$ & 2.0 & 653 & 0.8 & & \\
\hline Total & 2.0 & 1,117 & 0.8 & & \\
\hline \multicolumn{6}{|c|}{ Identification with extreme party } \\
\hline No $(=0)$ & 2.0 & 1,000 & 0.8 & \multirow[t]{3}{*}{0.1} & \multirow[t]{3}{*}{$* * *$} \\
\hline Yes $(=1)$ & 1.7 & 117 & 0.7 & & \\
\hline Total & 2.0 & 1,117 & 0.8 & & \\
\hline \multicolumn{6}{|c|}{ Identification with mainstream party } \\
\hline No $(=0)$ & 2.0 & 770 & 0.8 & \multirow[t]{3}{*}{0.1} & \multirow[t]{3}{*}{ n.s. } \\
\hline Yes $(=1)$ & 2.1 & 347 & 0.8 & & \\
\hline Total & 2.0 & 1,117 & 0.8 & & \\
\hline \multicolumn{6}{|l|}{ Pride in democratic transition } \\
\hline No $(=0)$ & 1.6 & 141 & 0.7 & \multirow[t]{3}{*}{0.2} & \multirow[t]{3}{*}{$* * *$} \\
\hline Yes $(=1)$ & 2.0 & 984 & 0.8 & & \\
\hline Total & 2.0 & 1,125 & 0.8 & & \\
\hline \multicolumn{6}{|c|}{ Positive evaluation of pre-1974 regime } \\
\hline No $(=0)$ & 2.0 & 868 & 0.8 & \multirow[t]{3}{*}{0.0} & \multirow[t]{3}{*}{ n.s. } \\
\hline Yes $(=1)$ & 1.9 & 233 & 0.8 & & \\
\hline Total & 2.0 & 1,101 & 0.8 & & \\
\hline \multicolumn{6}{|l|}{ Economy } \\
\hline Got worst $(=0)$ & 1.8 & 305 & 0.7 & \multirow[t]{3}{*}{0.2} & \multirow[t]{3}{*}{$* * *$} \\
\hline Got better (=1) & 2.0 & 716 & 0.8 & & \\
\hline Total & 2.0 & 1,021 & 0.8 & & \\
\hline \multicolumn{6}{|l|}{ Public Policies } \\
\hline Got worst $(=0)$ & 1.8 & 105 & 0.8 & \multirow[t]{3}{*}{0.1} & \multirow[t]{3}{*}{ * } \\
\hline Got better $(=1)$ & 2.0 & 923 & 0.8 & & \\
\hline Total & 2.0 & 1,028 & 0.8 & & \\
\hline \multicolumn{6}{|l|}{ Risk and Uncertainty } \\
\hline Got worst $(=0)$ & 2.0 & 975 & 0.8 & \multirow[t]{3}{*}{0.0} & \multirow[t]{3}{*}{ n.s. } \\
\hline Got better $(=1)$ & 1.9 & 123 & 0.9 & & \\
\hline Total & 2.0 & 1,098 & 0.8 & & \\
\hline Correlations & Pearson & Sig & & $N$ & \\
\hline Traditional vs. liberal values & 0.2 & & & 1,235 & \\
\hline
\end{tabular}

Source: Barometer 40 Years of Democracy in Portugal (2014).

Notes: ${ }^{*} p<0.05 ;{ }^{* *} p<0.01 ;{ }^{* * *} p<0.001 ;$ n.s. $=$ non significant; S.E. $=$ Standard Error.

\section{The determinants of satisfaction with democracy in Portugal: main results}

Table 3 presents the results of four OLS regression models with various predictors of satisfaction with democracy, aiming to test both supply- and demand-side accounts. Model 1 only includes socio-demographics and largely confirms our expectations: when we control for gender, level of education, employment and religiosity, age appears to be the most relevant variable in this group, those citizens who were born after 1974 being more satisfied with democracy. In other words, those who underwent part or most of their political socialisation under the Estado Novo regime are more dissatisfied with the way democracy works in the country. However, it should be noted that the model in itself has very weak explanatory power, which concurs with previous scholarship that has found limited effects of socio-demographics on attitudes towards democracy.

Model 2 adds variables for political attitudes and values orientation. The results show that those with no party identification or identifying with a mainstream party tend to 
be more satisfied with democracy than those identifying with extreme parties. These results suggest two immediate conclusions. Firstly, having no party identification does not necessarily mean that citizens are less satisfied with democracy. This is an important finding, as a substantial strand of literature posits that decreasing levels of partisanship driven by lack of trust in political parties are among the many symptoms of democratic crisis in Western countries (Dalton 2004). Secondly, citizens' identification with more polarised parties bears significantly on lower levels of satisfaction with democracy. This suggests a certain degree of congruence with these parties' (PCP and BE) tendency to be more critical of representative democracy and the democratic performance of governments. ${ }^{6}$

Table 3. Determinants of satisfaction with democracy.

\begin{tabular}{|c|c|c|c|c|}
\hline Variables & Model 1 & Model 2 & Model 3 & Model 4 \\
\hline \multicolumn{5}{|l|}{ Socio-demographics } \\
\hline Men & $0.02(0.05)$ & $0.03(0.06)$ & $0.05(0.06)$ & $0.06(0.06)$ \\
\hline Born after $1954^{\mathrm{a}}$ & $-0.14(0.05)^{* *}$ & $-0.15(0.07)^{*}$ & $-0.13(0.07)^{\dagger}$ & $-0.08(0.07)$ \\
\hline Born before $1954^{a}$ & $-0.27(0.07)^{* * *}$ & $-0.23(0.08)^{* *}$ & $-0.22(0.08)^{* *}$ & $-0.21(0.09)^{*}$ \\
\hline Education & $0.04(0.05)$ & $0.03(0.06)$ & $0.00(0.07)$ & $-0.04(0.07)$ \\
\hline Employed & $-0.08(0.05)^{\dagger}$ & $-0.12(0.06)^{*}$ & $-0.15(0.06)^{*}$ & $-0.16(0.07)^{*}$ \\
\hline Religiosity & $-0.07(0.05)$ & $-0.11(0.06)^{\dagger}$ & $-0.12(0.06)^{\dagger}$ & $-0.11(0.07)$ \\
\hline \multicolumn{5}{|l|}{ System of values and political attitudes } \\
\hline Traditional vs. liberal values & & $0.02(0.02)$ & $0.01(0.02)$ & $0.00(0.02)$ \\
\hline No party identification ${ }^{b}$ & & $0.25(0.09)^{* *}$ & $0.28(0.09)^{* *}$ & $0.23(0.09)^{*}$ \\
\hline Identification with mainstream party ${ }^{b}$ & & $0.34(0.09)^{* * *}$ & $0.37(0.09)^{* * *}$ & $0.38(0.10)^{* * *}$ \\
\hline \multicolumn{5}{|l|}{ Evaluation of country's political past } \\
\hline Pride in democratic transition & & & $0.55(0.08)^{* * *}$ & $0.52(0.09)^{* * *}$ \\
\hline Positive evaluation of pre-1974 regime & & & $0.00(0.07)$ & $-0.04(0.08)$ \\
\hline \multicolumn{5}{|l|}{ Democratic performance } \\
\hline Economy & & & & $0.28(0.08)^{* * *}$ \\
\hline Social policies & & & & $0.08(0.12)$ \\
\hline Risk and uncertainty & & & & $0.01(0.10)$ \\
\hline Constant & $2.17(0.06)^{* * *}$ & $1.89(0.12)^{* * *}$ & $1.42(0.14)^{* * *}$ & $1.19(0.17)^{* * *}$ \\
\hline Number of observations & 1,232 & 825 & 731 & 613 \\
\hline$R^{2}$ & 0.02 & 0.04 & 0.10 & 0.13 \\
\hline Adjusted $R^{2}$ & 0.02 & 0.03 & 0.08 & 0.11 \\
\hline
\end{tabular}

Source: Barometer 40 years of Democracy in Portugal (2014).

Notes: Unstandardised coefficients with standard errors in brackets. All models were estimated on STATA with the command regress. Given the nature of the dependent variable ordered logit regressions were also performed for cross-validation purposes (command omodel logit). The results hold across all models; and can be provided upon request. ${ }^{\text {The reference }}$ category is 'born after 1974 '. ' $T$ The reference category is 'identification with mainstream party'. ${ }^{\dagger} p<0.10 ;{ }^{*} p<0.05 ;{ }^{* *} p<$ $0.01 ;{ }^{* * *} p<0.001$.

On the contrary, sharing a more liberal (vs. traditional) system of values appears to have no significant effect on satisfaction with democracy in Portugal. As discussed elsewhere in this article, the correlation between these two variables has already proved to be unclear in the framework of previous studies (however, the variables used were different from ours).

In model 3 we test the last set of demand-side explanations: whether the way citizens perceive and evaluate the country's past political experience influences their current appraisals of democracy. The results reveal a significant and positive effect of being proud of the way Portugal has gone through its democratic transition upon levels of satisfaction with democracy (the highest coefficient in the model). Contrarily, whether individuals consider the Estado Novo regime to have had more positive than negative effects is irrelevant for their level of satisfaction with the way democracy works. It is worth noting that age, not having a 
party identification, and identification with a mainstream party remain statistically significant correlates of satisfaction with democracy and that the overall quality of the model improves (the explained variance almost triples vis-à-vis model 2).

Finally, model 4 tests the effect of supply-side explanations of satisfaction with democracy by adding three variables that express whether citizens think governments' performance in the areas of economic development, social policies implementation, and reduction of risk and uncertainty has improved or not with respect to the pre-1974 regime. The results show that the economy is the sole category bearing a statistically significant effect on satisfaction with democracy, and it is a positive one. In other words - and corroborating a series of previous studies - positive evaluations of the country's economic performance lead to higher levels of satisfaction with democracy. Significant effects previously encountered still hold in this model - with the exception of 'born after 1954'.

\section{Concluding notes}

Forty years after the Carnation Revolution, the relatively young Portuguese democracy is experiencing dramatically low levels of specific support for democracy at the citizen level. This article sought to uncover the sources of this phenomenon by testing a set of demandside and supply-side explanations suggested by the vast literature on citizens' attitudes towards democracy. This was done by reframing the analysis of individual factors that have been considered in previous studies (such as age and party identification) and by estimating the explanatory power of unique variables, such as those measuring attitudes towards the democratic transition and the previous authoritarian regime.

By and large, this article makes three main contributions to the existing scholarship on specific support for democracy in Portugal. Firstly, it shows that political socialisation and political culture theories can offer a good contribution to the understanding of public satisfaction with democracy. On the one hand, our results confirm the existence of cohort effects on satisfaction with democracy: those citizens, who were fully socialised in the democratic era (were born after 1974) exhibit higher levels of specific support for the democratic regime than those who were partly or completely socialised under the Estado Novo regime. On the other hand, we found that the particular mode of Portugal's democratisation has a significant effect on public satisfaction with democracy: those who feel proud of how the transition to democracy was carried out in the country also tend to be more satisfied with the current state of the democracy (this was actually one of the most relevant predictors in our models). Following Pinto (2006) and Fishman (2011), we can see these findings as a reflection of a specific legacy of Portugal's transition to democracy. The transition's powerful dynamic - the state crisis that followed the ruptura revolution, and social movements - triggered a strong 'reaction to the past' and contributed to the shaping of an explicitly pro-democratic culture, which works through several agents of socialisation and information in society and which also manifests in social and political practices and discourses.

Secondly, our analysis suggests that different political attitudes, here framed in terms of no party identification and identification with mainstream or extreme parties, have a significant effect on specific support for democracy. Above all, it is those citizens who feel closer to extreme parties who express lower levels of satisfaction with the way democracy works in Portugal. This finding is important for two reasons. On the one hand, it countervails those 
arguments positing that decreasing levels of partisanship and distrust in political parties are a signal of disengagement from democracy. If that were the case in Portugal, then we should expect lower levels of satisfaction with democracy among those citizens who do not feel close to any political party; and our analysis proves otherwise. On the other hand, our results could encourage scholars to reconsider how democracy is framed in terms of party competition both on the supply (parties') and on the demand (citizens') side, as these factors indirectly suggest congruence between parties and their supporters: more ideologically polarised voters tend to express lower levels of specific support for democracy. These results make even more sense if we consider that in Portugal extreme-left parties have been systematically left out of the government, and perhaps for that reason tend to assume more critical stances towards the democratic performance of the elected governments (in terms of both principles and outcomes) (see, e.g., similar results in Freire [2015]). Thus, it is logical to assume that their supporters also perceive a greater democratic deficit. Nonetheless, further research should be carried out to ascertain the degree of congruence between parties' and citizens' understandings and evaluations of democracy.

Lastly, this article has corroborated the existing scholarship that considers economic factors to be one of the most relevant supply-side predictors of satisfaction with democracy. As our analysis has demonstrated, what matters the most for Portuguese citizens' evaluations of democracy is their perception of whether the economy has or has not improved. Additional research is needed in order to evaluate possible intervening effects of the economic crisis on these results.

\section{Notes}

1. For technical details of this survey see Lobo, Pinto and Magalhães (2016).

2. EuroBarometer, July 2014 , http://ec.europa.eu/public_opinion/archives/eb/eb81/eb81_anx_ en.pdf (accessed July 2015).

3. Question wording is, 'Could you please tell me how do you evaluate the following changes that Portugal underwent in the past years: do you consider them more positive than negative or more negative than positive: (a) increase in number of working women; (b) increase in number of unmarried couples living together; (c) increase in divorces; $(d)$ increase in number of births outside marriage; (e) increase in the number of immigrants; and ( $f$ ) decrease in number of children per couple.'

4. Question wording is, 'On the following aspects, and compared with the situation before April 25 , do you think things in Portugal are better, stayed the same or are worse?' From the 16 items under evaluation the following 12 were chosen: economic situation, standard of living, health care, corruption, criminality and insecurity, unemployment, inequality between regions, inequality between rich and poor, education, housing, justice and social security.

5. The Cronbach's alpha for these indexes are, respectively, $0.7,0.7$ and 0.8 .

6. We arrived at a similar conclusion using left-right self-placement as an alternative variable: those who place themselves at the extreme left and at the extreme right are less satisfied with democracy than those closer to the centre.

\section{Acknowledgments}

The authors would like to thank the editors of this journal and two anonymous reviewers for their insightful comments. For very useful comments on an earlier version of this article, we thank the members of the Social and Political Attitudes Research Group at the Institute of Social Sciences University of Lisbon, in particular, Pedro Magalhães, Goffredo Adinolfi and Marina Costa Lobo. This 
article was written in the framework of the 'Barometer of the Quality of Democracy' project, supported by the Portuguese Fundação para a Ciência e a Tecnologia (strategic project no. UID/SOC/50,013/2013) and by the Fundação Calouste Gulbenkian.

\section{Disclosure statement}

No potential conflict of interest was reported by the authors.

\section{Notes on contributors}

Edalina Rodrigues Sanches is a postdoctoral researcher at the Institute of Social Sciences (University of Lisbon), at the Portuguese Institute of International Relations (New University of Lisbon) and at the Centre for Social Science Research (University of Cape Town). Her research interests include political institutions and political behaviour in new democracies.

Ekaterina Gorbunova is a PhD candidate and member of the 'Barometer of the Quality of Democracy' at the Institute of Social Sciences (University of Lisbon). Her research has focused on democratisation and quality of democracy, political attitudes and political culture, global governance and educational policy.

\section{References}

Aarts, K. \& Thomassen, J. (2008) 'Satisfaction with democracy: do institutions matter?', Electoral Studies, vol. 27, pp. 5-18.

Anderson, C. J., Blais, A., Bowler, S., Donovan, T. \& Listhaug, O. (2005) Losers' Consent, Oxford University Press, New York, NY.

Anderson, C. J. \& Guillory, C. A. (1997) 'Political institutions and satisfaction with democracy: a crossnational analysis of consensus and majoritarian systems', The American Political Science Review, vol. 91 , no. 1, pp. 66-81.

Anderson, C. J. \& Singer, M. M. (2008) 'The sensitive left and the impervious right: multilevel models and the politics of inequality, ideology, and legitimacy in Europe', Comparative Studies, vol. 41, no. 4-5, pp. 564-599.

Cho, W. (2004)'Political institutions and satisfaction with democracy in sub-saharan Africa', AfroBarometer, Working Paper no. 39.

Clarke, H. D., Dutt, N. \& Kornberg, A. (1993) 'The political economy of attitudes toward polity and society in western european democracies', The Journal of Politics, vol. 55, no. 4, pp. 998-1021.

Curini, L., Jou, W. \& Memoli, V. (2012) 'Satisfaction with democracy and the winner-loser debate: the role of policy preferences and past experience', British Journal of Political Science, vol. 42, no. 2, pp. 241-261.

Dalton, R. J. (2004) Democratic Challenges, Democratic Choices, Oxford University Press, Oxford.

Easton, D. (1975) 'A re-assessment of the concept of political support', British Journal of Political Science, vol. 5, no. 4, pp. 435-457.

Ekman, J. \& Linde, J. (2005) 'Communist nostalgia and the consolidation of democracy in Central and Eastern Europe', Journal of Communist Studies and Transition Politics, vol. 21, no. 3, pp. 354-374.

Evans, G. \& Whitefield, S. (1995) 'The politics and economics of democratic commitment: support for democracy in transition societies', British Journal of Political Science, vol. 25, no. 4, pp. 485-514.

Fishman, R. M. (2011) 'Democratic practice after the revolution: the case of Portugal and beyond', Politics and Society, vol. 39, no. 2, pp. 233-267.

Freire, A. (2003) 'Desempenho da democracia, representação e reformas políticas: o caso português em perspectiva comparada', Sociologia, Problemas e Práticas, vol. 43, pp. 133-160. 
Freire, A. (2015) 'The condition of Portuguese democracy during the Troika's intervention, 2011-2014: government-opposition, regime support \& political trust', Paper prepared for the 9th ECPR General Conference, Montreal, Canada, 26-29 August 2015; available online at: http://ecpr.eu/Filestore/ PaperProposal/d678b9e5-c73d-405e-9156-768125ed4ed9.pdf.

Fuchs, D. \& Klingemann, H.-D. (1990) 'The left-right schema', in Continuities in Political Action. A Longitudinal Study of Political Orientations in Three Western Democracies, eds M.K. Jennings et al., Walter de Gruyter, Berlin/New York, pp. 203-234.

Fuchs, D. \& Roller, E. (2006) 'Learned democracy? Support of democracy in Central and Eastern Europe', International Journal of Sociology, vol. 36, no. 3, pp. 70-96.

Giddens, A. (1990) The Consequences of Modernity, Polity Press, Cambridge.

Gherghina, S. (2010) 'Attitudes towards the communist past in five Central and Eastern European countries', History of Communism in Europe: Politics of Memory in Post-Communist Europe, vol. 1, pp. 165-179.

Gorbunova, E., Sanches, E. R. \& Lobo, M. C. (2015) 'A satisfação com a democracia e os fatores explicativos. Portugal no contexto europeu', in Portugal Social em Mudança 2015, eds J. Ferrão \& A. Delicado, Imprensa de Ciências Sociais, Lisboa, pp. 9-17.

Inglehart, R. \& Welzel, C. (2003) 'Political culture: analyzing cross-level linkages', Comparative Politics, vol. 36, no. 1, pp. 61-79.

Inglehart, R. \& Welzel, C. (2005) Modernization, Cultural Change, and Democracy: The Human Development Sequence, Cambridge University Press, New York, NY.

Jalali, C. (2009) 'No meio está a virtude? As preferências e posições de eleitores e partidos nas legislativas de 2005', in As Eleições Legislativas e Presidenciais 2005-2006 Campanhas e escolhas eleitorais num regime semipresidencial, eds M.C. Lobo \& P. Magalhães, Imprensa de Ciências Sociais, Lisboa, pp. $155-182$.

Kim, M. (2009) 'Cross-national analyses of satisfaction with democracy and ideological congruence', Journal of Elections, Public Opinion and Parties, vol. 19, no. 1, pp. 49-72.

Kittilson, M. C. \& Scarrow, S. E. (2003) 'Political parties and the rhetoric and realities of democratization', in Democracy Transformed?, eds B.E. Cain, R.J. Dalton \& S.E. Scarrow, Oxford University Press, Oxford, pp. 59-80.

Lambert, R. D., Curtis, J. E., Brown, S. D. \& Kay, B. J. (1986) 'Effects of identification with governing parties on feelings of political efficacy and trust', Canadian Journal of Political Science, vol. 19, pp. 705-728.

Lobo, M. C., Pinto, A. C. \& Magalhães, P. (2016) 'Portuguese democratisation 40 years on: its meaning and enduring legacies', South European Society and Politics, vol. 21, no. 2, pp. 163-180.

Lobo, M. C. \& Magalhães, P. C. (2011) 'Room for manoeuvre: euroscepticism in the Portuguese parties and electorate 1976-2005', South European Society and Politics, vol. 16, no. 1, pp. 81-104.

Magalhães, P. C. (2005) 'Disaffected democrats: political attitudes and political action in Portugal.' West European Politics, vol. 28, no. 5, pp. 973-991.

Magalhães, P. C. (2014) 'Government effectiveness and support for democracy', European Journal of Political Research, vol. 53, pp. 77-97.

Magalhães, P. C., Lobo, M. C. \& Gorbunova, E. (2014) 'Significados e avaliações da democracia: as visões dos cidadãos e da classe política', Boletim Atitudes Sociais dos Portugueses. vol 3, Instituto de Ciências Sociais, Lisboa.

Mishler, W. \& Rose, R. (1994) 'Support for parliaments and regimes in the transition toward democracy in Eastern Europe', Legislative Studies Quarterly, vol. 19, no. 1, pp. 5-32.

Morlino, L. \& Montero, J. R. (1995) 'Legitimacy and democracy in Southern Europe', in The Politics of Democratic Consolidation: Southern Europe in Comparative Perspective, eds R. Gunther, P.N. Diamandouros \& J.-J. Puhle, Johns Hopkins University Press, Baltimore, MD, pp. 231-260.

Norris, P. (2011) Democratic Deficit, Cambridge University Press, Cambridge.

Pereira, J. S. \& Sanches, E. R. (2014) 'Portugal', in Parties for Europe, Parties against Europe Party Attitudes Towards the EU in the Member States, ed N.Conti, Routledge, New York, pp. 115--132.

Pharr, S. \& Putnam, R., eds (2000) Disaffected Democracies: What's Troubling the Trilateral Countries? Princeton University Press, Princeton.

Pinto, A. C. (2006) 'Authoritarian legacies, transitional justice and state crisis in Portugal's democratization', Democratization, vol. 13, no. 2, pp. 173-204. 
Polavieja, J. (2012) 'The great recession: political trust, satisfaction with democracy and attitudes to welfare-state redistribution in Europe', available online at: http://repec.imdea.org/pdf/imdeawp2012-08.pdf

Schäfer, A. (2010) 'Affluence, inequality and satisfaction with democracy', The Max Planck Institute for the Study of Societies. available online at: http://www.mpifg.de/people/as/downloads/Affluence_ Inequality.pdf.

Teixeira, C. P., Tsatsanis, E. \& Belchior, A. M. (2014) 'Support for democracy in times of crisis: diffuse and specific regime support in Portugal and Greece', South European Society and Politics, vol. 19, no. 4, pp. 501-518.

Torcal, M. \& Lago, I. (2006) 'Political participation, information, and accountability. Some consequences of political disaffection in new democracies', in Political Disaffection in Contemporary Democracies. Social capital, institutions, and politics, eds M. Torcal \& J.R. Montero, Routledge, London \& New York, pp. 308-331.

Torcal, M., \& Magalhães, P. C. (2009) 'Political culture in Southern Europe: searching for exceptionalism', available online at: http://www.pedro-magalhaes.org/PDFs/PoliticalCultureinSouthernEuropemarc. pdf.

Torcal, M., \& Montero, J. R. (2006) Political Disaffection in Contemporary Democracies: Social Capital, Institutions and Politics, Routledge, London \& New York. 